\title{
Design of compound cross-section critical flow flumes for PT channel by using WinFlume software
}

K. KRUPAVATHI, K. KISHAN AND H.V. HEMA KUMAR

Received : 21.06.2016; Revised : 26.08.2016; Accepted : 11.09 .2016

See end of the Paper for authors' affiliation

Correspondence to :

\section{K. KRUPAVATHI}

College of Agricultural

Engineering, Bapatla, GUNTUR (A.P.) INDIA

Email : krupareddy572@gmail.

com
- ABSTRACT : Accurate discharge measurement in open channels is essential for water resources planning, water and sediment budget analysis, hydrologic modeling, reservoir operation, flood mitigation. Long-throated flumes are coming into general use in discharge measurement because they can be easily fitted into complex channel shapes as well as simple shapes. And also provide cost-effective, practical and flexible capabilities for measuring discharge. 'Winflume' software allows the user to calibrate the existing design and to make new design of long throated flume. Based on channel dimensions and conditions of canal an attempt is made to theoretically design a new flume to measure the discharge accurately. With so many iterations, three acceptable designs were considered with compound cross-sections. The three designs were further studied for hydraulic flow conditions. Among the three flumes, the flume with trapezoidal compound crosssection resulted the best performance.

- KEY WORDS : WinFlume, Discharge, Canal

- HOW TO CITE THIS PAPER : Krupavathi, K., Kishan, K. and Kumar, H.V. Hema (2016). Design of compound cross-section critical flow flumes for PT channel by using WinFlume software. Internat. J. Agric. Engg., 9(2) : 166-172, DOI: 10.15740/HAS/IJAE/9.2/166-172. 